\title{
МОТИВАЦИОНА ФУНКЦИЈА УЏБЕНИКА РУСКОГ ЈЕЗИКА ЗА СРЕДЬУ БОГОСЛОВСКУ ШКОЛУ (КОНСТРУКЦИЈСКА РЕШЕЊА НА ПЛАНУ МАКРОСТРУКТУРЕ $)^{1}$
}

Мотивација се сматра општим покретачем за све облике људског деловања, па тако и учења. Управо зато мотивациона функција уџбеника страног језика има велики значај. У овом раду анализирају се конструкцијска решења која се инкорпорирају у све компоненте макроструктуре уџбеника - текстове (теоријско-спознајне, инструментално-практичне, инструменталне) и вантекстуалне компоненте (апаратура организације усвајања, апаратура оријентације, илустративни материјал). Анализа се спроводи на уџбеницима руског језика за средњу богословску школу - прва и друга година учења. Добијени резултати могу наћи примену у наставној пракси, као и у конструисању и експертизи уџбеника.

Кључне речи: лингводидактика, уџбеник руског језика као страног, мотивација, мотивациона функција уџбеника, макроструктура уџбеника.

Motivation is considered to be a general trigger for all forms of human behaviour including learning. For that reason, a motivational function of a textbook for second-language learning bears important meaning. In this paper, we analyze the constructional solutions that can be incorporated in all the components of a textbook macrostructure, such as a textual macrostructure (theoretical and cognitive, instrumental and practical), as well as out of textual components (the apparatus for the organization of acquisition, the apparatus for orientation, illustrative material). The analysis is applied to the textbooks of Russian for high school (the first and the second year of learning). The results of this work can be useful for teaching practice, as well as for a good quality textbook development.

Keywords: linguodidactics, textbook of Russian as a foreign language, motivation, motivational function of a textbook, macrostructure of a textbook.

У општој теорији уџбеника, после разраде структурно-садржајног модела уџбеника (о историјату разраде овог модела исп. детаљније Кончаревић 2002: 13-20, 59-72, 161-165), дошло је до осмишљавања функционалног приступа. У дидактичкој литератури класичном и незаобилазном се сматра класификација коју је предложио Д. Д. Зујев, а која обухвата осам функција уџбеника: 1. информациону, 2. трансформациону, 3. функцију систематизације, 4. функцију утврђивања и самоконтроле рада, 5. функцију самообразовања, 6. интегративну, 7. координативну и 8. развојно-васпитну функцију (Зујев 1988: 49-68). Ови елементи нису хијерархијски поређани, али је јасно да се групишу у три комплекса функција - програмске $(1,2,3)$, методичке $(4,6,7)$ и психолошке $(5,8)$, свакако са могућношћу даљег допуњавања (аутор и сам наглашава да је у питању отво-

\footnotetext{
${ }^{1}$ Одломак из мастер рада, који је добио награду „Проф. др Радмила Милентијевић“ 2017. године. Рад је израђен под менторским руководством проф. др Ксеније Кончаревић.
} 
рен систем, подложан допунама и реинтерпретацијама). Ипак, као недостатак овог система функција уочавамо недовољну структурисаност класификације по нивоима посматрања (примарне и изведене функције) и превелики број елемената. У покушају стварања једне оперативне класификације од значаја нам је била и концепција Ј. Малића, који уочава две функције уџбеника - информациону и трансформациону, међу којима нема хијерархијске надређености и подређености (Malić 1986: 26-28). Као критеријум за издвајање ова два елемента узети су, очигледно, нивои објект-знања у уџбенику (исп. Требјешанин 2001: 76-77), али се превиђа уграђеност у уџбеник још једне врсте знања - метазнања, и пропуштено је да се у оквиру ових примарних функција, на следећој равни анализе, издвоје секундарне функције. Значајан утицај на нас је извршила и таксономија општих захтева (метафункција уџбеника) коју налазимо у: Пешић 1998: 24-26, а која укључује три елемента: (а) обезбеђивање што ефикасније и ефектније комуникације (преношења програмских садржаја), (б) омогућавање смисленог и активног учења (структурисања активности ученика), и (в) остваривање развојне улоге уџбеника (развоја личности ученика). Недостатак ове класификације, по нашем виђењу, јесте то што није извршено њено даље рашчлањивање на нижим нивоима анализе, које би омогућило њену конкретизацију и већу операционалност. Зато смо покушали да понудимо рашчлањенију класификацију, у којој као додатни критеријум фигурирају природа и нивои знања у уџбенику. Дакле, на основу три метафункције које уочава J. Пешић - комуникативне, педагошке и психолошке - издвајамо три функционална комплекса који су им адекватни: (а) информациони, (б) трансформациони и (в) развојни. Комплекси (а) и (б) усмерени су на посредовање објект-знања, при чему у (а) доминирају декларативна («знања да»), а у (б) процедурална («како да») и кондиционална знања («како и зашто»), док је комплекс (в) усмерен превасходно на посредовање метазнања (в. Требјешанин 2001: 71-75). При даљој анализи могуће је у оквиру сваког комплекса издвајати основне функције које улазе у његов састав: у комплексу (а) издвојили бисмо 1. функцију трансмисије културе, 2. функцију посредовања лингвистичких садржаја и 3. функцију посредовања комуникативних садржаја, у (б) 1. функцију појашњавања, 2. утврђивања, 3. резимирања и систематизације градива, 4. (ауто)контроле и (ауто)корекције, 5. интегративну и 6. координативну, а у (в) 1. метакогнитивну, 2. мотивациону и 3. функцију индивидуализације. Пионирски рад о могућностима примене функционалног приступа анализи уџбеника руског језика написала је К. Кончаревић (Кончаревич 2007).

Већина радова из области теорије уџбеника страних језика значајно место међу функцијама уџбеника придаје мотивационој функцији, која је предмет нашег истраживања. У теорији уџбеника руског језика као страног њу посебно издвајају и образлажу И. Л. Бим (Бим 1981: 13-16), В. И. Шљахов (Шляхов 1982: 8-24), А. Н. Шчукин (Щукин 1984: 95-99), А. Р. Арутјунов (Арутюнов 1987: 63-67), К. Кончаревић (Кончаревић 2002: 151-159), Ј. И. Пасов (Пассов 1989: 6-17), В. Раичевић (Раичевић 2007: 320-331). Најразрађенији систем параметара за процењивање реализовања мотивационе функције при експертизи уџбеника, независно од њихове методичке оријентације, типологије и намене (профила и етапе учења коју опслужују) нуди А. Р. Арутјунов, предлажући пре- 
цизне критеријуме за процену мотивисаности наставне делатности у уџбенику у материјалима презентације, преткомуникативног увежбавања, комуникативне праксе, трансфера, као и у материјалима намењеним текућем стимулисању ученика (Арутюнов 1987: 63-67). По овим критеријумима, уз извесне модификације, извршили смо валоризацију апаратуре мотивације у домаћим средњошколским уџбеницима руског језика израђеним по когнитивном и комуникативном методу. У овом раду намера нам је да сагледамо мотивационе потенцијале уџбеника израђених у оквиру најновије, културолошке парадигме наставе руског језика, конституисане у другој половини 90-их година. Реч је о уџбеницима који се користе у српској говорној и социокултурној средини, намењеним почетном усвајању руског језика у средњем стручном профилу (богословије). За овај истраживачки проблем определили смо из разлога што уџбеници намењени почетном овладавању страним језиком у средњој школи представљају, по нашем мишљењу, највећи методолошки изазов за састављаче, нарочито са становишта реализовања њихове мотивационе функције. Наиме, на овом нивоу снажно је изражена диспропорција између ограниченог фонда језичких средстава којима ученици располажу и ступња њихове интелектуалне развијености, између интелектуално-спознајне «неискоришћености» традиционалних часова извођених у духу когнитивног или комуникативног приступа и потребе за пуновредном комуникацијом. Додатни изазов везан је за почетно овладавање језиком струке. Робовање лингвистички оскудном материјалу у почетној етапи учења страног језика неминовно доводи до примитивизације интелектуалног и спознајног нивоа уџбеника, који управо због фрапантног размимоилажења са потребама и афинитетима ученика узрокују губљење мотивације за учење већ на самом старту (Кончаревић 2001: 335-345). Да би се премостио јаз између нивоа интелектуалне развијености ученика узраста од 15-18 година и когнитивног дефицита традиционалних уџбеника, окренутих искључиво реализовању прагматичког циља наставе, у новијој генерацији уџбеника за средње стручне школе, како ћемо видети из излагања које следи, настоји се да се управо из мотивационо-стимулационих разлога изгради принципијелно нови приступ њиховом екстралингвистичком садржају.

Функционални модел анализе и описа уџбеника реализује се тако што се (а) у оквиру сваког функционалног комплекса посматрају организациони принципи који руководе креирањем и конструисањем конкретних уџбеничких решења и (б) у оквиру сваке функције посматрају структурно-системска средства која омогућавају њену реализацију. У русистичкој функционалној теорији уџбеника у оквиру (а) анализирани су принцип доступности релевантних знања и искустава и принцип јасноће и стабилности знања (Кончаревић 2009), а у оквиру (б) функције развијајућег функционалног комплекса - функција индивидуализације и диференцијације (Кончаревић 2009), функција аутоконтроле, аутокорекције и аутоевалуације (Кончаревић 2008), метакогнитивна (Кончаревић 2006) и култура служења школском књигом (Кончаревић 2011).

Значај мотивационе функције уџбеника наглашава и програмски документ који је обавезујући за ауторе, рецензенте и спољне евалуаторе уџбеника у српској средини (Ивић и др. 2008). Према овом документу, „уџбеник не би смео да своју улогу сведе само на пуку неутралну презентацију академски валидних знања, 
већ би морао, кад год је то могуће, да пронађе или направи мост између тих садржаја и карактеристика младе генерације (њеног сензибилитета, интереса и интересовања, потреба, вредносних оријентација, ставова и погледа на свет)“ (Ивић и др. 2008: 57). Аутори између осталог истичу да је релевантност садржаја за ученике уједно и средство да се повећа мотивациона вредност уџбеника, јер ученици могу да примене та знања у свом животу, да их употребе за властиту социјалну промоцију и сл. Овакво осмишљавање садржаја и повећања мотивације за учење из уџбеника знатно повећава вероватноћу да ће бар неки садржаји из уџбеника постати саставни део њиховог живота и њихове личности, а тиме се обезбеђује трајност и употребљивост тих знања.

У литератури се истиче да се мотивациона функција као конституента развојног функционалног комплекса остварује низом конструкцијских решења на равни текстотеке (проблематизација градива на равни текста, коришћење технике «романа у наставцима», односно прекидања излагања на одређеним - пожељно је на најузбудљивијим местима, укључивање допунских текстова «за радознале»), апаратуре организације усвајања (прибегавање проблемској, комуникативно-спознајној формулацији инструкција, укључивање дидактичких игара и вежби за «откривање» језичких законитости), апаратуре оријентације (провокативни наслови лекција, текстова, уџбеничких блокова, анонси са неконвенционалним формулацијама циљева и садржаја лекције), илустративног материјала и ликовно-графичке обраде уџбеника.

У даљем излагању размотрићемо потенцијале одређених структурних елемената уџбеника који су нам послужили као корпус за истраживање у реализовању мотивационе функције и издвојити позитивна конструкцијска решења.

Апаратура организације усвајања располаже значајним мотивационим потенцијалом. У обликовању вежбања, питања, задатака и радних налога, који сачињавају апаратуру организације усвајања, мотивациону функцију имају инструкције, посебно ако су обликоване неформално, затим обраћање пажње ученицима на нове моменте у усвајању градива (осмишљавање интерферентних и фацилитационих појава), као и скретање пажње са лингвистичких на екстралингвистичке појаве, односно на задатке и радне налоге који имају изразито мотивациону функцију. На нивоу апаратуре организације усвајања мотивациона функција може се реализовати посредством вербалних инструкција о радњи коју треба извршити (оне најчешће представљају стандардну компоненту структуре вежбања). Ова функција је утолико наглашенија уколико су вежбања осмишљена не као банална «комуникација ради комуникације» или као пуки материјал за оперисање језичким елементима, него као још једно од средстава за задовољавање реалних когнитивних и комуникативних потреба. Овакву усмереност имају пре свега вежбе чија је сврха самостално обликовање садржаја (комуникативне у правом смислу), где ученик ступа у општење руководећи се сопственим мотивима, самостално бирајући лексичко-граматичка средства и самостално обликујући садржајни план исказа. Међутим, са становишта комуникативног приступа пожељно је да и преткомуникативни и условно-комуникативни типови вежбања буду пропраћени неконвенционалним инструкцијама, које би ученике ангажовале и интелектуално, и емоционално-доживљајно, стварајући уједно свест о потреби изграђивања одређених језичких навика 
са становишта њихове комуникативне и спознајне сврсисходности. Успешно решавање овог типа вежби захтева, дакле, психолошки добро осмишљену и за ученике атрактивну инструкцију (која се, управо у циљу постизања пуновреднијег односа аутора уџбеника са учеником, с обзиром на ограниченост методичке терминологије и лексичких средстава уопште којима ученик влада, у почетним фазама учења може дати и на матерњем језику). Навешћемо неколико примера:

- а) Помози Наташи да представи своју браћу. Употреби по смислу компаративе: выше, старше, моложе, меньше, лучше, хуже.

Наташе 16 лет. Она среднего роста (167 cм). В иколе ей нравится история и литература, но по физике и химии у нее всегда тройки. У нее два брата, Андрей и Саша. Андрею 14 лет, а Саше 20. Андрей маленького роста (164 см), а Саша-высокого (182 cм). Андрей не любит заниматься. Саша учится на факультете. У него очень хорошие отметки.

- У меня два брата, Андрей и Сама. Андрей м Отметки у него х , чем у меня. Саша с $u M$ , чем я. успехи в школе $л$ , чем у меня.

б) Шта би могао да каже Андреј? А Сама?

в) Шта би ти могао да испричаш о својој породици? (РО: 109). Захваљујући комуникативној инструкцији, вежбање које је у суштини усмерено на имитацију, посматрање и уочавање везе између облика и садржине - што је од неопходне важности у почетном стадијуму оперисања језичким материјалом - у свести ученика «надрасло» је оквире делања по задатом обрасцу и попримило комуникативну усмереност).

- Редакција московског часописа «Встреча» ступила је у контакт са једном католичком богословијом из Париза како би објавила текст о начину живота и рада у њиховој школи. Која су питања била постављена да би се добили овакви одговори? Запиши их!

? Наша школа называется "Сен-Сюльпис». ? Она находится в Париже. ? В ней учится сто семинаристов. ? $И x$ возраст - 23-30 лет. ? После окончания семинарии они принимают священный сан. ? Семинаристы изучают богословские дисииплины, философию, иностранные языки. коние каждого полугодия. ? В семинарии организуются экскурсии в католические монастыри. ? Парижские семинаристы учатся четьре дня в неделю. Среда, суббота и воскресенье для них свободные дни (ПД: 41; оперишући језичким и говорним материјалом уведеним у тексту ученик може сазнати много занимљивих детаља о животу и раду једне париске богословије).

- Замисли овакве ситуачије:

а) Распитујеш се код свог колеге где се налази продавнииа православне литературе. Он ти даје адресу, а ти га молиш за детаљнија разјашњења како да стигнеш донде.

б) Дошао си на жељено место. Обраћаш се продавачици са молбама да ти покаже енциклопедију «Хришћанство», књигу Светог Варсонуфија, икону 
Светитеља Николаја и календар (при томе варираш реченичне конструкиије), а она те ьубазно услужује.

в) У библиотеци Московске богословије обраћаш се библиотекару с молбом да ти помогне: потребне су ти књиге Светог Тихона Задонског. Он ти каже да ове књиге постоје у библиотеци, али ти истовремено саветује да их купиш у продавници «Православна књига»; на твоје распитивање, објасниће ти и где се она налази.

У ситуачијама а) и в) можеш да користиш и ове речи и изразе:

Как пройти к...? Как проехать к...? Как дойти до...?

Это близко // недалеко отсюда... // недалеко от...

Иди(те) прямо до улицы...

Поверни(те) налево, направо (РО: 194-195). Вежбање за трансфер у коме су сви елементи ситуације дати на матерњем језику ученика, чиме се постиже активизација језичког и говорног материјала уведеног у лекцији).

Поред наведених вежбања, који подстичу ученике на размишљање и самостални рад, подстицајни су и одељци типа: Покажи се, докажи се, Потражи - истражи, За вас, радознали, различити квизови итд. Веома често они омогућавају и индивидуализацију и диференцијацију у оквиру фронталног, групног и рада у паровима.

У општедидактичкој литератури потенцијали текстотеке у изграђивању и одржавању мотивације углавном се не констатују (Пешић 1998: 165-167). Међутим, наводи се да значајну улогу у изграђивању мотивације имају инструктивни текстови, намењени излагању алгоритма мисаоних и говорних операција те практичних радњи усмерених на развијање ученичких способности за самостални рад, укључујући и самостално служење књигом (детаљније в. у: Кончаревић 2002: 95-97). Ова категорија текстова, потенцијално веома разуђена по типологији (упутства типа алгоритма, инструкције, савета, демонстрације и стимулуса (Пассов 1989: 106-108, 157, 180 ), није довољно заступљена у домаћим уџбеницима руског језика, иако пружа изванредне могућности за управљање самосталним радом, аутоконтролом, аутокорекцијом и аутоевалуацијом ученика. Зато ћемо навести примере из нашег корпуса анализираних уџбеника у којима запажамо подстицање ученика на коришћење других, додатних извора знања (чиме се актуализује координативна и усмеравајућа функција самог уџбеника) и тражење нових информација, као и давање конкретних предлога и сугестија којима се та активност организује и усмерава:

- Интернет пружа изванредне могућности за праћење руске штампе и целокупног издаваштва. Сада имаш довољно знања да можеш разумети велики број информација на руском језику које су ти посредством Интернета доступне за свега неколико секунди.

Најзначајнија адреса на којој ћеш наћи информаиије везане за Руску православну иркву јесте http://www.or.rи (на овом сајму, између осталог, можеш да читаш и Интернет-верзије неколико руских духовних часописа). 
Ако те интересује световна итампа, потражи адресу www.nns.ru, где Национална информативна служба Русије свакодневно даје избор из руских новина и часописа. Многе новине и часописи у потпуности презентирају свој садржај на Интернету (тако ћеш, рецимо, на адреси www.ng.rи свакодневно моћи да читаш популарну "Независимую газету»).

Уколико ти током читана затреба објашњене неке непознате речи, прикључи се на портал dic.acadeтіс.ги и, када одабереш речник, за 1-2 секунде добићеш потребно тумачење (РО: 193).

Подстицање наставка учења, усвајања и примене знања у свакодневном животу такође је важан задатак уџбеника. Материјалима за аутоконтролу и аутоевалуацију, које треба систематски инкорпорирати у уџбеник страног језика, ученик може стећи не само увид у сопствена постигнућа, него и стимулус за даље активности на плану повећавања обима и нивоа комуникативне и лингвокултуролошке компетенције. Навешћемо један пример из финалног дела једног уџбеника - тумачења резултата анкете у којој су ученици процењивали своја постигнућа у усвајању руског језика по шест параметара:

- Свако заокружено „а“ “ заслужује велику похвалу: стартовао си изврсно, остаје ти само да одржаваш ниво, а то ти неће бити тешко, пошто си, очигледно, и талентован и заинтересован.

Одговори под „б“ “ такође показују солидан почетак. На оно што си до сада постигао нова знања ћеш сигурно успешно надовезивати, само ако будеш редовно учио и обнављао градиво.

Тамо где си заокружио „в“" треба да даш све од себе да поправиш успех. Сада то још увек можеш да урадиш: преко распуста поново, пажљљиво и лаганим темпом, проради књигу, научи оно ито си пропустио. Открићеш да градиво није било тако тешко, да је требало само радити редовно и бити активан на часу. А следеће године ћеш окренути нови лист, прионућеш на посао и... имати најмање четворку! (ПД: 152)

Треба обратити пажњу и на анонсе текстова, који представљају водич кроз путовања до циља-савладавање градива и стицање знања и умења. Они су у свакој лекцији уџбеника треба да буду једнаке структуре. Њихова функција је, поред мотивационе, и у томе да уливају ученику сигурност да у савладавању градива нису сами. То видимо из примера:

\section{Урок 1 (первый)}

\section{Шта ћемо научити?}

- да се представимо, поздравимо, обратимо

- да поставимо питање

\section{Сазнаћемо...}

- како изгледа школовање у руским богословијама

- која су најчешћа руска имена

Упознаћемо друге...

- са својим пријатељима и школским друговима

- са својом иколом 
Умећемо да...

- одредимо род именице

- препознамо одредбе за место и правач

- искажемо радњу која се збива у садашњости (ПД, стр. 151-152)

Још један од елемената мотивационе функције уџбеника чине и наслови њихових целина (лекција), као што су: Знакомиться легко - расставаться трудно; Язык до Киева доведет; Ветви лозы Христовой; Друзья мои, прекрасен наш союз! итд.

Обраћање аутора ученицима такође је веома релевантно када је однос ученика према уџбенику у питању. Важно је постићи пријатељски став аутора у обраћању кроз инструкције за израду вежби и друге сегменте уџбеника. Истиче се ученик као индивидуа, али се подстиче и групни рад.

Уџбеник реализује своје мотивационе потенцијале тако што омогућава ученику да средствима језика који се учи остварује задатке општења сферама комуникације актуелним за ученика. Материјал за рад представљају реалне чињенице комуникације. Аутентичност материјала доводи до стварања «ефекта природности»: радећи по уџбенику, ученици изводе комуникативне операције које би у аналогним условима изводили и сами носиоци језика, с том разликом што селекција и алгоритам тих операција могу бити нешто другачији у односу на функционисање језика у изворној говорној средини, и што су те комуникативне операције пропраћене извесним незаобилазним, чисто наставним операцијама. Другим речима, преткомуникативни елементи морају бити инкорпорирани у комуникативни уџбеник као неопходан предуслов за остваривање циљане комуникације, али у обиму и на начин који је условљен њеним реализовањем.

У уџбенику у коме је наглашена мотивациона функција настоји се да се све прелама кроз призму личности ученика - његове потребе, интересовања, узрасне и индивидуално-психолошке одлике, а то налази одраза у уџбеничким садржајима, карактеру општења аутора са корисницима књиге и нарочито у диференцираним формама презентације и актуелизације наставних садржаја.

Екстралингвистички садржај текстуалних материјала, узрасно релевантан, психолошки подстицајан и високо информативан, даје снажан стимулус за интензивније усвајање језичке грађе. За разлику од традиционалних уџбеника, који се на почетном нивоу оријентишу пре свега на сферу животне свакодневице - а на узрасту од 14-15 година то се доживљава као недопустиво «приземни», баналан садржајни оквир, анализирани уџбеници показују тенденцију да се, као прво, комуникативно незаобилазна сфера свакодневице по правилу повезује са ученицима далеко атрактивнијом социокултурном и сфером масмедија. Повезивање сфере свакодневице са културолошком сфером није резултирало редукцијом информативности у оквирима ове потоње: одабир реалија културе извршен је по критеријуму репрезентативности, тако да ученици о Русији сазнају оно без чега је незамисливо образовање културних људи данашњице, људи европских видика. Додајмо овоме и оријентацију на међукултурно општење, на дијалог култура као контекст у који је смештено овладавање језиком, што подразумева двоструку улогу ученика као примаоца и даваоца информација. У процесу учења, напоредо са усавајањем језика, 
откривају се и истоветности, сличности и разлике у националним социокултурним стереотипима општења. У уџбеницима које смо анализирали се као компонента апаратуре организације усвајања у оквиру сваке лекције дају сегменти «Увек се колебам» реализовани у форми дијалога младића из Србије и Русије, чији је циљ уочавање и објашњавање разлика у језику и у тзв. «језику уобичајеног понашања», одн. невербалним конвенцијама прихваћеним у свакој конкретној националној средини. У истој функцији су, напоредо са основним инструментално-практичним, заступљени и лингвокултуролошки текстови на матерњем језику пропратног карактера у односу на тематски оквир лекције и лексички минимум који га опслужује (сегменти «Јеси ли већ чуо да...», «Ово је занимљиво»). Оволико придавање значаја екстралингвистичком (нарочито културолошком) садржају резултирало је још једном новом појавом: уградњом специјалних задатака и вежбања чијом израдом и они ученици који заостају у овладавању језиком могу да демонстрирају своју ерудицију и лингвокултуролошку компетенцију, чиме ће компензирати недостатке у другим димензијама предметне компетенције - а то је са тачке гледишта подстицања мотивације од изузетне важности. Такав карактер имају дидактичка игра «Квиз» у свакој лекцији, као и извесна вежбања која нису издвојена у посебну рубрикациону јединицу, а чија је израда условљена ослањањем на визуелни ослонац.

Анализирани уџбеници руског језика, као што смо показали, материјализују поставке комуникативне методике у бројним аспектима свога структурног и садржинског обликовања, представљајући велики корак напред у односу на традиционалне лингвистичке и преткомуникативне уџбенике. Усуђујемо се да тврдимо да су овако конципиране школске књиге, којима циљ није једино тај да покажу како је структурисан руски језик и помогну да се њиме практично овлада, него и да понуде неке од одговора на питање шта је вечна Русија и у чему је непролазна вредност руске културе, кадре да одговоре изазовима времена у коме живимо са знатно поколебаном мотивацијом за изучавање овога великог светског језика (из екстралингвистичких разлога). И још нешто: пракса декларативног опредељивања за комуникативно-индивидуализовани приступ природно је уступила место конкретним трагањима и изналажењима решења за уношење у педагошки процес оних методичких достигнућа којима је русистика већ увелико располагала.

\section{Цитирана литература}

Арутюнов, А. Р. Конструирование и экспертиза учебника. Москва: Институт русского языка им. А. С. Пушкина, 1987.

[Arutiûnov, A. R. Konstruirovanie i èkspertiza uchebnika. Moskva: Institut russkogo iâzyka im. A. S. Pushkina, 1987]

Бердичевский, А. Л. «Как поддержать внутреннюю мотивацию в изучении русского языка». Русский язык в центре Европы 3 (2000): 55-59.

[Berdichevskiĭ, A. L. «Kak podderzhat' vnutrenniưiu motivatsîu v izuchenii russkogo iâzyka». Russkiĭ iâzyk v țentre Evropy 3 (2000): 55-59]

Бим, И. Л. «Ключевые проблемы теории учебника: структура и содержание». [In:] Л. Б. Трушина (сост.). Содержание и структура учебника русского языка как иностранного. Москва: Институт русского языка им. А. С. Пушкина, 1981: 9-17.

[Bim, I. L. „Kliūchevye problemy teorii uchebnika: struktura i soderzhanie“. [In:] L. 
B. Trushina (sost.). Soderzhanie i struktura uchebnika russkogo iāzyka kak inostrannogo. Moskva: Institut russkogo iāzyka im. A. S. Pushkina, 1981: 9-17]

Зујев, Д. Д. Школски уџбеник. Београд: Завод за уџбенике и наставна средства, 1988.

[Zujev, D. D. SHkolski udzbenik. Beograd: Zavod za udzbenike i nastavna sredstva, 1988]

Ивић, Иван, Ана Пешикан и Слободанка Антић. Водич за добар уџбеник - општи стандарди квалитета уџбеника. Нови Сад: Платонеум, 2008.

[Ivich, Ivan, Ana Peshikan i Slobodanka Antich. Vodich za dobar udzbenik - opshti standardi kvaliteta udzbenika. Novi Sad: Platoneum, 2008]

Кончаревић, Ксенија. „Мотивациона функција културолошког уџбеника руског језика у инословенској средини: проблеми и решења“. Зборник Института за педагошка истраживања 33 (2001): 335-345.

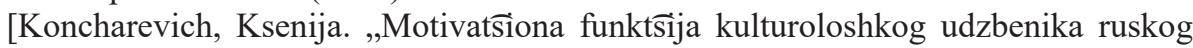
jezika u inoslovenskoj sredini: problemi i reshenja“. Zbornik Instituta za pedagoshka istrazhivanja 33 (2001): 335-345]

Кончаревић, Ксенија. Савремени уџбеник страног - руског језика: структура и садржај. Београд: Завод за уџбенике и наставна средства, 2002.

[Koncharevich, Ksenija. Savremeni udzbenik stranog - ruskog jezika: struktura i sadrzhaj. Beograd: Zavod za udzbenike i nastavna sredstva, 2002]

Кончаревић, Ксенија. „Метакогнитивна функција савременог уџбеника руског језика у инословенској средини: проблеми и решења“. [In:] J. Вучо (прир.). Уџбеник у настави страних језика, Никшић: Универзитет Црне Горе - Филозофски факултет, 2003: 75-94.

[Koncharevich, Ksenija. „Metakognitivna funktsija savremenog udzbenika ruskog jezika u inoslovenskoj sredini: problemi i reshenja“. [In:] J. Vucho (prir.). Udzbenik u nastavi stranikh jezika, Nikshiћ: Univerzitet TSrne Gore - Filozofski fakultet, 2003: 75 -94]

Кончаревић, Ксенија. „Функција индивидуализације и диференцијације у уџбенику страног (руског) језика: теоријски принципи и конструкцијска решења“. [In:] J. Вучо, Б. Милатовић (прир.). Индивидуализација и диференцијација у настави страних језика. Никшић: Универзитет Црне Горе - Филозофски факултет, 2009: 162-171.

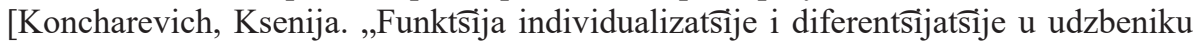
stranog (ruskog) jezika: teorijski printșipi i konstruktsึijska reshenja“. [In:] J. Vucho, B.

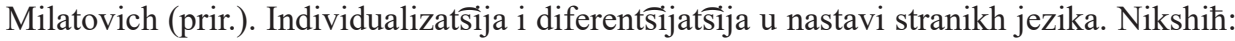
Univerzitet TSrne Gore - Filozofski fakultet, 2009: 162-171]

Кончаревич, Ксения. «Новый подход к структуре учебника РКИ (теоретические принципы и решения в плане конструирования)». [In:] Мир русского слова и русское слово в мире. Сборник докладов 11 конгресса МАПРЯЛ (Варна, 21-25 сентября 2007.). Том 6 (2): Методика преподавания русского языка (родного, неродного, иностранного. София: Heron Press, 2007: 215-222.

[Koncharevich, Kseniiā. «Novyı̌ podkhod k strukture uchebnika RKI (teoreticheskie printsipy i resheniiā v plane konstruirovaniia)». [In:] Mir russkogo slova i russkoe slovo v mire. Sbornik dokladov 11 kongressa MAPRIAL (Varna, 21-25 sentiabriā 2007.). Tom 6 (2): Metodika prepodavaniiâ russkogo iâzyka (rodnogo, nerodnogo, inostrannogo. Sofiiâ: Heron Press, 2007: 215-222]

Кончаревич, Ксения. «Поощрение автономии учащихся в обучении русскому языку в инославянской среде при помощи учебника». [In:] Б. Станкович (ред.), Русский язык как инославянский. Современное изучение русского языка и русской культуры в инославянском окружении. Белград: Славистическое общество Сербии, 2010: 128-133. 
[Koncharevich, Kseniiā. „Pooshchrenie avtonomii uchashchikhsiā v obuchenii russkomu iâzyku v inoslaviānskoĭ srede pri pomoshchi uchebnika“". [In:] B. Stankovich (red.), Russkiı̌ iâzyk kak inoslaviânskī̌. Sovremennoe izuchenie russkogo iâzyka i russkoĭ kul'tury v inoslaviânskom okruzhenii. Belgrad: Slavisticheskoe obshchestvo Serbii, 2010: 128-133]

Пассов. Е. И. Основы коммуникативной методики обучения иноязычному общению. Москва: Русский язык, 1989.

[Passov. E. I. Osnovy kommunikativnoĭ metodiki obucheniiāinoiāzychnomu obshcheniiū. Moskva: Russkiı̌ iâzyk, 1989]

Пешић, Јелена. Нови приступ структури уџбеника. Теоријски принципи и конструкцијска решења. Београд: Завод за уџбенике и наставна средства, 1998.

[Peshich, Jelena. Novi pristup strukturi udzbenika. Teorijski printsipi i konstruktşijska reshenja. Beograd: Zavod za udzbenike i nastavna sredstva, 1998]

Раичевић, Вучина. Русистичка лингводидактика: теорија и пракса. Београд: Славистичко друштво Србије, 2017.

[Raichevich, Vuchina. Rusistichka lingvodidaktika: teorija i praksa. Beograd: Slavistichko drushtvo Srbije, 2017]

Требјешанин, Биљана, Душанка Лазаревић (прир.). Савремени основношколски уџбеник. Теоријско-методолошке основе. Београд: Завод за уџбенике и наставна средства, 2001.

[Trebjeshanin, Biljana, Dushanka Lazarevich (prir.). Savremeni osnovnoshkolski udzbenik. Teorijsko-metodoloshke osnove. Beograd: Zavod za udzbenike i nastavna sredstva, 2001]

Шляхов, В. И. Индивидуализация обучения и проблемы создания самоучителя русского языка. Автореф. дисс. канд. пед. наук. Москва: Институт русского языка им. А. С. Пушкина, 1982.

[SHliakhov, V. I. Individualizatsiīâ obucheniiâ i problemy sozdaniiâ samouchiteliā russkogo iâzyka. Avtoref. diss. kand. ped. nauk. Moskva: Institut russkogo iāzyka im. A. S. Pushkina, 1982]

Щукин, А. Н. Методика краткосрочного обучения русскому языку как иностранному. Москва: Институт русского языка им. А. С. Пушкина, 1984.

[SHCHukin, A. N. Metodika kratkosrochnogo obucheniiā russkomu iâzyku kak inostrannomu. Moskva: Institut russkogo iāzyka im. A. S. Pushkina, 1984]

Malić, Josip. Koncepcija suvremenog udžbenika. Zagreb: Školska knjiga, 1986.

\section{Извори}

ПД-Первый диалог. Уџбеник за први разред српских православних богословија. Београд: Св. арх. Синод СПЦ, 2000.

[PD - Pervyî dialog. Uџbenik za prvi razred srpskikh pravoslavnikh bogoslovija. Beograd: Sv. arkh. Sinod SPTS, 2000]

РО - Радость общения. Уџбеник за други разред српских православних богословија. Београд: Св. арх. Синод СПЦ, 2001.

[RO - Radost' obshcheniiâ. Uџbenik za drugi razred srpskikh pravoslavnikh bogoslovija. Beograd: Sv. arkh. Sinod SPTS, 2001] 
Кристина Микавица

\title{
МОТИВАЦИОННАЯ ФУНКЦИЯ УЧЕБНИКА РУССКОГО ЯЗЫКА ДЛЯ СРЕДНИХ БОГОСЛОВСКИХ УЧИЛИЩ (РЕШЕНИЯ В ПЛАНЕ КОНСТРУИРОВАНИЯ НА УРОВНЕ МАКРОСТРУКТУРЫ)
}

\begin{abstract}
Резюме
Мотивация считается общим двигателем всех форм поведения, в том числе и обучения. Именно поэтому мотивационная функция учебника иностранного языка является более важной, чем кажется на первый взгляд. В предлагаемой работе анализируются решения в плане конструирования учебника, которые внедряются в каждый из компонентов его макроструктуры - в тексты (теоретико-познавательные, инструментально-практические, инструментальные), а также во внетекстуальные компоненты (имеется в виду аппаратура организации усвоения, аппаратура ориентации, иллюстративный материал). Анализ проводится на корпусе учебников русского языка для первого и второго года обучения в средней (высшей) школе. Полученные результаты могут найти применение в преподавательской практике, а также при конструировании и экспертизе учебников.

Ключевые слова: лингводидактика, учебник русского языка как иностранного, мотивация, мотивационная функция учебника, макроструктура учебника.
\end{abstract}

